\title{
SISTEM PENGANGGARAN DALAM KEBUDAYAAN HINDU TERKAIT IMPLEMENTASI KONSEP TRI HITA KARANA (PARAHYANGAM) DI LINGKUNGAN UNDIKSHA
}

\author{
Ni Made Indah Hemayani, Kadek Noviani, \\ Heri Hermawan, Ni Luh Novitasari Catalina P.M \\ Jurusan Akuntansi, Universitas Pendidikan Ganesha, Singaraja, Bali, Indonesia
}

\begin{abstract}
Abstrak
Penelitian ini bertujuan untuk mengetahui bagaimana sistem penganggaran di Undiksha, bagaimana faktor-faktor yang mendasari undiksha menerapkan sistem penganggaran tersebut dan Bagaimana implementasi sistem penganggaran di undiksha terhadap konsep Tri Hita Karana (parahyangan). Jenis penelitian yang digunakan pada penelitian ini adalah jenis metode kualitatif. peneliti menggunakan teknik wawancara dengan mewawancarai salah seorang pihak dari rektorat yang bernama Bapak Nyoman Surewijaya,S.E. selaku Bendahara di Universitas Pendidikan Ganesha. Sistem penganggaran yang dilakukan Undiksha merupakan sistem penganggaran yang telah ditetapkan oleh pusat dengan penganggaran yang tidak mencantumkan anggaran untuk kerohanian. Selain itu ormawa-ormawa yang menerapakan sistem tersebut adalah ormawa-ormawa yang kegiatannya bersumber dari dana pusat yang diperoleh melalui Rektorat Undiksha. Faktor-faktor yang mendasari Undiksha melaksanakan sistem tersebut diantaranya anggaran dana yang diperoleh oleh undiksha merupakan dana yang bersumber dari KEMENRISTEKDIKTI (Pusat), pembuatan RAB (Rencana Anggaran Biaya) berpedoman pada peraturan pemerintah pusat, pengeluaran kerohanian sulit untuk dibuatkan Surat Pertanggungjawaban (SPJ), dan pengeluaran kerohanian yang bersifat tidak universal.
\end{abstract}

Kata kunci: Penganggaran, RAB, Tri Hita Karana

\begin{abstract}
This study aims to find out how the budgeting system in Undiksha, how the factors that underlie undiksha apply the budgeting system and how the implementation of the budgeting system in Undiksha against the concept of Tri Hita Karana (parahyangan). This type of research used in this study is a type of qualitative methods. The researcher used interview technique by interviewing one of the parties from the rector named Mr. Nyoman Surewijaya, S.E. as Treasurer at Ganesha University of Education. Undiksha budgeting system is a budgeting system that has been set by the center with a budget that does not include a budget for spirituality. In addition, the organizations implementing the system are those whose activities are sourced from central funds obtained through the Undiksha Rectorate. Factors underlying Undiksha to implement the system include budget funds obtained by undiksha from funds originating from the Ministry of Research and Technology (Central), making the $R A B$ (Budget Plan) based on central government regulations, spiritual expenditure is difficult to make a Letter of Responsibility (SPJ), and spiritual expenditures that are not universal.
\end{abstract}

Keywords: Budgeting, RAB, Tri Hita Karana

\section{Pendahuluan}

Bali merupakan salah satu provinsi di Indonesia yang sampai saat ini masih menjunjung tinggi kearifan lokal dan aspek religius dalam pelaksanaan kegiatan sehari-hari. Kearifan lokal dan aspek religius yang sangat kental ini menyebabkan segala perbuatan yang di lakukan tidak lepas dari kearifan lokal dan aspek-aspek religius keagamaan yaitu agama Hindu.

Aspek religius ini merupakan cerminan konsep Tri Hita Karana yang pada hakekatnya terdiri dari Parahyangan, Palemahan, dan Pawongan. Hakikat ajaran Tri Hita Karana juga diungkapkan oleh I Ketut Wiana (2004:141) yang menekankan tiga hubungan manusia dalam kehidupan di dunia ini. Ketiga hubungan itu meliputi hubungan dengan sesama manusia, hubungan dengan alam sekeliling, dan hubungan dengan ke Tuhan yang saling 
terkait satu sama lain. Unsur-unsur di dalam Tri Hita Karana harus dilaksanakan secara utuh danterpadu dalam mengimplementasikannya.

Universitas Pendidikan Ganesha (Undiksha) merupakan salah satu perguruan tinggi di Bali yang sangat menjunjung tinggi konsep Tri Hita Karana. Hal mengenai konsep Tri Hita Karana tersebut juga sudah diatur dalam Visi Undiksha yaitu "menjadi universitas unggul berlandaskan falsafah Tri Hita Karana di Asia pada tahun 2045". Konsep Tri Hita Karana tersebut diimplementasikan melalui proses penganggaran suatu kegiatan. Konsep Tri Hita Karana yang tercantum dalam penganggaran biasanya adalah mengenai parahyangan yakni dana kerohanian di setiap kegiatan. Anggaran yang telah disusun tersebut digunakan untuk membeli sarana-prasarana keagamaan.

Tri Hita Karana terdiri dari tiga kata yakni Tri yang berarti tiga, Hita yang berarti kebahagiaan atau kesejahteraan dan karana yang berarti sebab. Arti Tri Hita Karana adalah tiga komponen atau unsur yang menyebabkan kesejahteraan atau kebahagiaan. Ketiga komponen Tri Hita Karana itu berkaitan erat antara yang satu dengan yang lainya. Ketiga komponen Tri Hita Karana ini meliputi tiga unsur yakni hubungan harmois antara manusia dengan Tuhan, hubungan harmonis manusia dengan sesama, dan hubungan manusia dengan lingkungan. (sudarta,2008:84)

Mulyadi (2001) menyatakan bahwa anggaran merupakan suatu rencana kerja yang dinyatakan secara kuantitatif yang diukur dalam satuan moneter standar dan satuan ukuran yang lain yang mencakup jangka waktu satu tahun. Sedangkan, Penganggaran adalah suatu rencana keuangan periodik yang disusun berdasarkan program-program yang telah disahkan (Nafarin, 2000). Untuk mengendalikan pengeluaran dalam suatu kegiatan, perlu dilakukannya suatu penganggaran. Penyusunan anggaran merupakan faktor penting yang harus dibahas secara matang dan penerapannya harus optimal. Proses dari penyusunan anggaran biasanya dilakukan sebelum kegiatan berlangsung. Anggaran pada dasarnya merupakan alat penting untuk perencanaan dan pengendalian jangka pendek yang efektif dalam organisasi maupun lembaga. Suatu anggaran operasi biasanya menyatakan pendapatan dan beban yang direncanakan dalam kegiatan tersebut.

Berdasarkan masalah diatas, adapun rumusan masalah yang dilakukan yaitu bagaimana sistem penganggaran di Undiksha, bagaimana faktor-faktor yang mendasari undiksha menerapkan sistem penganggaran tersebut, Bagaimana implementasi sistem penganggaran di undiksha terhadap konsep Tri Hita Karana (parahyangan)

\section{Metode}

\section{Tempat Penelitian}

Penelitian yang dilakukan oleh peneliti bertempat di Universitas Pendidikan Ganesha, yang bertempat di Singaraja Buleleng, Bali. Penelitian dilakukan pada bulan November 2018 dan pemerosesan data dilakukan pada bulan Desember 2018. Untuk wawancara dalam memperoleh data-data yang diinginkan bertempat di Gedung Rektorat Undiksha di Lantai III, tepatnya pada Sub Bagian Keuangan Rektorat Undiksha, dengan narusumber yang digunakan pada penelitian ini adalah Bapak Nyoman Surewijaya,S.E.

\section{Jenis Penelitian}

Jenis penelitian yang digunakan pada penelitian ini adalah jenis metode kualitatif. Penelitian kualitatif juga dapat dimaknai sebagai rangkaian kegiatan penelitian yang mengembangkan pola pikir induktif dalam menarik suatu kesimpulan dari suatu fenomena tertentu. Pola berfikir Induktif ini adalah cara berfikir dalam rangka menarik kesimpulan dari sesuatu yang bersifat khusus kepada yang sifatnya umum. Dengan pendekatan ini peneliti dapat memperoleh gambaran yang lengkap dari permasalahan yang dirumuskan dengan memfokuskan pada proses dan pencarian makna dibalik fenomena yang muncul dalam penelitian, dengan harapan agar informasi yang dikaji lebih bersifat komprehensif, mendalam, alamiah dan apa adanya. (Anonim, 2017)

Dalam metode kualitatif instrumennya adalah orang, yaitu peneliti itu sendiri. Peneliti adalah instrumen kunci, untuk dapat menjadi instrumen, maka peneliti harus memiliki 
wawasan dan bakal teori yang luas sehingga mampu bertanya, menganalisis, memotret dan mengkontruksi situasi sosial yang diteliti menjadi lebih jelas dan bermakna. (Suryana, 2010)

Data yang digunakan dalam penelitian ini merupakan data primer yang peneliti peroleh secara langsung dari pihak yang memang benar-benar mengetahui secara pasti aturan yang telah berlaku di Undiksha ini yaitu dengan melakukan wawancara langsung kepada pegawai di Sub Bagian Keuangan.

Lebih lanjutnya mengenai populasi dan sampel yang digunakan. Populasi yang digunakan adalah Ormawa yang ada di Lingkungan Universitas Pendidikan Ganesha, sedangkan untuk sampelnya yaitu BEM, HMJ/HMPS, dan juga UKM.

\section{Objek Penelitian}

Dalam silabus yang telah disebarkan terdapat beberapa bahasan yang dapat digunakan, karena dasar tersebut maka penelti menggunakan sistem penganggaran yang dipengaruhi oleh kebudayaan yang ada di daerah setempat. Penganggaran yang dilakukan pada RAB mengenai kegiatan-kegiatan yang ada di Ormawa itu terdapat ketidak transparasi dalam pengerjaannya, sehingga diperlukan pengetahuan yang mendalam atas ketentuan yang telah ditetapkan dari pusat tersebut.

\section{Teknik Pengumpulan Data}

Menurut Sugiyono $(2013 ; 231)$ teknik pengumpulan data merupakan langkah paling strategis dalam penelitian, karena tujuan utama dari penelitian adalah mendapatkan data. Dalam melakukan penelitian ini, peneliti menggunakan 3 teknik pengumpulan data yang ada yaitu dengan cara:

1. Teknik Wawancara

Menurut Esterberg dalam Sugiyono (2013;231) wawancara merupakan pertemuan dua orang untuk bertukar informasi dan ide melalui tanya jawab, sehingga dapat dikontruksikan makna dalam suatu topik tertentu. Dalam penelitian ini, peneliti menggunakan teknik wawancara dengan mewawancarai salah seorang pihak dari rektorat yang bernama Bapak Nyoman Surewijaya,S.E. selaku Bendahara di Universitas Pendidikan Ganesha.

2. Teknik Pengamatan/Observasi

Sutrisno Hadi dalam Sugiyono $(2013 ; 145)$ mengemukakan bahwa, pengamatan atau observasi merupakan suatu proses yang kompleks, suatu proses yang tersusun dari berbagai proses biologis dan psikhologis. Observasi yang dilakukan adalah dengan observasi terus terang atau tersamar karena beberapa data yang kami perlukan dirahasiakan atau tidak terus terang dikatakan oleh narasumber.

3. Teknik Dokumentasi

Menurut Sugiyono $(2013 ; 240)$ dokumen merupakan catatan peristiwa yang sudah berlalu. Dokumen bisa berbentuk tulisan, gambar, atau karya-karya monumental dari seseorang. Studi dokumen merupakan pelengkap dari penggunaan metode observasi dan wawancara dalam penelitian ini. Untuk dokumen yang diperlukan dalam penelitian ini berkisaran pada aturan-aturan yang telah ditetapkan oleh KEMENRISTEKDIKTI mengenai cara pengSPJan yang seharusnya dibuat oleh pihak rektorat yang diteruskan kepada pihakpihak mahasiswa yang ada di Ormawa yang memberlangsungkan kegiatannya dengan memerlukan pendanaan dari pihak rektorat.

\section{Hasil dan Pembahasan}

\section{SISTEM PENGANGGARAN DI UNDIKSHA}

Pengertian penganggaran telah disebutkan sebelumnya bahwa penganggaran merupakan proses penyusunan secara sistematis mengenai setiap pengeluaran yang dilakukan dan jumlah pendanaan yang dimiliki atau diterima. Dalam penelitian yang telah sempat dilakukan untuk memperoleh suatu analisis yang menjawab sistem penganggaran yang diberlakukan di Undiksha terhadap adanya peraturan yang bersifat kebudayaan 
mengenai cara penganggaran terhadap kegiatan persembahyangan atau kelompok sie kerohanian pada $\mathrm{RAB}$ yang tidak dicantumkan secara terus terang pada laporan melainkan di pecah penganggaranya ke berbagai sie yang ada.

Seperti yang telah dijelaskan bahwa peneliti melakukan kegiatan penelitian di kawasan lingkungan Undiksha yakni Rektorat Undiksha dan Ormawa (Organisasi Mahasiswa). Setelah penelitian berhasil dilakukan dapat diketahui bahwa sistem penganggaran yang dianut pada Undiksha adalah sistem penganggaran yang sesuai dengan peraturan pusat yakni KEMENRISTEKDIKTI. Dari adanya penerapan aturan tersebut membuat pengeluaran yang berhubungan dengan keagamaan khususnya yang berhubungan dengan umat Hindu dilaporkan secara tidak transparan. Pemberlakuan aturan tersebut dilakukan karena, pengeluaran tersebut yang berhubungan dengan sie Kerohanian hanya lingkup di Bali saja, dan tidak mencapai pada lingkup nasional, sesuai yang dikatakan oleh Bapak Nyoman Surewijaya. Berhubungan dengan pendanaan universitas yang diperoleh dalam hal kegiatan operasionalnya berasal dari pusat, mau tidak mau universitas juga harus melalukan penyesuaian dengan aturan yang diberlakukan tersebut, sebagai bentuk atas pertanggungjawaban atau pemenuhan kewajiban atas hak yang diperoleh dalam pendanaan yang diberikan oleh pusat.

Dalam wawancara yang dilakukan bersama dengan Bapak Nyoman Surewijaya didapatkan bahwa segala bentuk pengeluaran yang dapat diakui sudah ada aturannya dalam acuan Standar Biaya Umumnya, sebagai contoh biaya perjalanan dinas, biaya trasnportasi lainnya yang dapat diakui sebagai bentuk pengeluaran atas dana yang didapatkan. (SBU terlampir) Maka dari itu setiap Ormawa yang memerlukan pendanaan yang berasal dari pihak rektorat yang diteruskan ke pusat harus mengikuti pula aturan yang ada ini, apabila dananya ingin dicairkan.

\section{FAKTOR-FAKTOR YANG MENDASARI UNDIKSHA MENERAPKAN SISTEM PENGANGGARAN}

Sebagaimana dengan aturan yang telah ditetapkan mengenai penggunaan pendanaan yang diberikan oleh pusat maka dalam melakukan penganggaran, Undiksha tidak mencantumkan anggaran dana untuk Kerohanian atau yang mengkhusus berhubungan dengan keagaaman Hindu karena sifatnya yang lokal atau berlaku di wilayah Bali saja. Adanya peraturan ini disebabkan oleh beberapa faktor yang dapat diperinci sebagai berikut adanya yaitu;

1. Anggaran Dana yang Diperoleh oleh Undiksha Merupakan Dana yang Bersumber dari KEMENRISTEKDIKTI (Pusat).

Menurut Peraturan Pemerintah Republik Indonesia Nomor 26 Tahun 2015 pasal 4 bahwa bantuan pendanaan PTN badan hukum, dialokasikan dalam anggaran pendapatan dan belanja negara setiap tahun anggaran pada kementrian yang menyelenggarakan urusan pemerintahan di bidang Pendidikan Tinggi sebesar $20 \%$ dan merupakan bagian dari alokasi anggaran fungsi pendidikan yang dikelola secara otonom dan bukan merupakan penerimaan negara bukan pajak. Dalam wawancara yang dilakukan dengan Bapak Nyoman Surewijaya,S.E. selaku Bendahara di rektorat Undiksha membenarkan bahwa dana yang diterima oleh Undiksha sendiri berasal dari pemerintah pusat. Sehingga segala pengeluaran yang dilakukan oleh rektorat baik itu kegiatan yang dilaksanakan oleh lembaga sendiri maupun ormawa-ormawa di Undiksha, maka peraturan yang digunakan tetap menerapkan peraturan yang ditetapkan di pusat.

2. Pembuatan RAB (Rencana Anggaran Biaya) Berpedoman pada Peraturan Pemerintah Pusat

Kegiatan yang dilakukan di Lingkungan Ormawa Undiksha biasanya memerlukan dana, dana yang dibutuhkan didapatkan dari proposal yang diajukan ke lembaga maupun ke dekanat di masing-masing fakultas. Setiap kegiatan yang dilaksanakan di Undiksha, baik itu dilaksanakan oleh Ormawa maupun lembaga itu sendiri akan membuat Rencana Anggaran Biaya (RAB). Rencana tersebut dibuat oleh bendahara sesuai dengan kebutuhan di setiap divisi atau sie yang membutuhkan. Rencana anggaran biaya tersebut akan disertakan 
dengan proposal kegiatan yang akan diajukan untuk memperoleh dana. Apabila dalam pengajuan dana yang dilakukan ormawa kepihak rektorat maka dana tersebut bersumber dari pusat, sehingga Rancangan Anggaran Biaya yang diajukan harus sesuai dengan strandar yang telah ditetapkan oleh pusat. Oleh karena itu dalam Rencana Anggaran Biaya tersebut tidak mencantumkan anggaran dana untuk kerohanian.

3. Pengeluaran Kerohanian Sulit untuk Dibuatkan Surat Pertanggungjawaban

Setiap barang yang dibuatkan surat pertanggungjawaban haruslah barang yang memiliki harga yang dapat diperkirakan, artinya harga tersebut sudah memiliki standar yang ditentukan. Berbeda halnya dengan biaya untuk kerohanian. Pengeluaran yang terjadi untuk kerohanian tidak terdapat didalam standar acuan biaya dikarenakan sifatnya yang fleksibel. Artinya biaya yang dikeluarkan tidak dapat dipastikan besarannya karena harga banten itu sendiri tidak ada ketetapan yang mengikat melainkan ditetapkan sendiri oleh penjual menurut pengeluaran pembelian bahan serta tingkat kerumitan dari banten tersebut. Hal itulah yang menyebabkan setiap harga banten berbeda di tempat satu dengan tempat lainnya.

4. Pengeluaran Kerohanian yang Bersifat Tidak Universal

Dana kerohanian merupakan pendanaan yang bersifat lokal artinya hanya berlaku untuk kelompok tertentu saja. seperti banten yang dikhususkan di daerah Bali saja karena mayoritas masyarakat Bali beragama Hindu. Hal tersebut selaras dengan pengakuan dari Bapak Nyoman Surewijaya,S.E. selaku Bendahara di Rektorat Undiksha bahwa biaya kerohanian tersebut bersifat mengkhusus dan berlaku hanya di daerah tertentu saja. Sehingga dalam kegiatan yang dilakukan di daerah Bali dan dananya bersumber dari daerah maka anggaran kerohanian dapat diakui dalam pembuatan RAB, karena pemerintah daerah sudah memiliki standar acuan biaya untuk kerohanian. Berbeda halnya dengan Undiksha yang berada di daerah Bali, tetapi dana yang diperoleh bersumber dari pusat sehingga dalam penganggaran dan pengelolaan dana kerohanian tidak dapat diakui karena menyesuaikan aturan pusat.

\section{IMPLEMENTASI SISTEM PENGAGGARAN DI UNDIKSHA TERHADAP KONSEP TRI HITA KARANA (PARAHYANGAN)}

Sistem penganggaran yang dilaksanakan oleh Pihak Universitas Pendidikan Ganesha (Undiksha) saat ini bukan merupakan sistem yang dilakukan dari pertama Undiksha berdiri, untuk saat ini pelaksanaan yang dilakukan berhubungan dengan aturan yang ditetapkan pada acuan standar biaya umum yang ada dan diberikan dari pusat sebagai bentuk untuk mengatur segala pengeluaran yang dilakukan oleh pihak universitas, agra terjadi kesesuaian dan pada saat dilakukan pemeriksaan oleh pusat tidak menimbulkan suatu permasalahan yang cukup berarti dan merepotkan atau membuat terjadinya penganggaran ulang.

Sebenarnya penggunaan atau implementasi dari sistem yang diberikan oleh pusat ini bermula dari pemeriksaan yang dilakukan oleh BPK. Sistem penganggaran yang dilakukan Undiksha adalah sistem dimana dalam penganggarannya mencantumkan anggaran untuk dana kerohanian. Hal itu dimaksudkan karena Undiksha ingin bahwa transpansi dari dana yang telah dikeluarkan tersebut. Namun hal tersebut berbeda pengertian setelah tim pemeriksa mempertanyakan mengenai standar acuan biaya yang dipergunakan dalam menganggarkan dana untuk kerohanian. Saat itu sampai sekarang Undiksha belum memiliki standar acuan biaya kerohanian yang jelas dan tepat, sehingga pemeriksa memberitahu bahwa Undiksha harus memperbaiki sistem penganggaran yang dilakukan dengan menggunakan sistem yang diterapkan pusat yakni sistem penganggaran tanpa mencantumkan anggaran untuk kerohanian.

Awal pengimplementasian dari sistem penganggaran yang tidak menganggaran dana untuk kerohanian tersebut tidak berjalan lancar. Ada beberapa hambatan yang menjadi kendala dari penerapan sistem tersebut. Menurut penuturan dari Bapak Nyoman Surewijaya,S.E. bahwa hambatan yang terasa saat penerapan sistem tersebut adalah menggantikan dan menyesuaikan sistem lama dengan sistem yang baru tersebut. Kesulitan 
pemahaman pengalihan dari penganggaran yang menganggarkan kerohanian ke penganggaran yang tidak menganggarkan kerohanian. Selain itu ormawa-ormawa yang mengalami kesulitan dalam pembuatan RAB. Rancangan Anggaran Biaya yang dibuat berdasarkan sistem penganggaran yang tanpa mencantumkan anggaran dana untuk kerohanian terdapat kesulitan yang terletak pada pemenuhan kebutuhan yang terjadi. Di mana ormawa-ormawa tersebut harus mendapatkan dana untuk kerohanian akan tetapi dana tersebut tidak dapat dianggarkan. Sehingga dalam hal ini kendala Undiksha adalah mengedukasi ormawa-ormawa kembali terkait dengan sistem penganggaran tanpa anggaran dana kerohanian tersebut.

Dalam pengimplementasiannya dari sistem penganggaran, dana yang digunakan untuk kerohanian tidaklah dicantumkan secara transparan dalam RAB yang dibuat melainkan disatukan pada pendanaan sie yang lainnya, dengan menaikkan kuantitas barang-barang yang diperlukan. Misalnya dalam kerohanian membutuhkan dana sebesar Rp 2.000.000 maka bendahara kegiatan akan meningkatkan kuantitas barang di sie yang dapat dianggarkan dalam RAB, seperti sie kesekretariatan, konsumsi, dan juga perlengkapan sampai dana yang dibutuhkan untuk pendanaan kerohanian dapat tercukupi. Sesuai dengan penuturan dari Bapak Nyoman Surewijaya bahwa dana tersebut tidak langsung dianggarkan di dalam RAB akan tetapi diselipkan atau mengambil dana dari sie lain. Beliau juga menuturkan bahwa bendahara kegiatan akan meningkatkan kuantitas barang di setiap sie yang mudah untuk di manipulasi. Sehingga dana yang kita butuhkan itu dapat terpenuhi tanpa ada hambatan.

\section{Simpulandan Saran}

\section{SIMPULAN}

Dari penelitian yang telah dilaksanakan bahwa dapat disimpulkan bahwa sistem penganggaran yang dilakukan Undiksha merupakan sistem penganggaran yang telah ditetapkan oleh pusat dengan penganggaran yang tidak mencantumkan anggaran untuk kerohanian. Selain itu ormawa-ormawa yang menerapakan sistem tersebut adalah ormawaormawa yang kegiatannya bersumber dari dana pusat yang diperoleh melalui Rektorat Undiksha. Faktor-faktor yang mendasari Undiksha melaksanakan sistem tersebut diantaranya anggaran dana yang diperoleh oleh undiksha merupakan dana yang bersumber dari KEMENRISTEKDIKTI (Pusat), pembuatan RAB (Rencana Anggaran Biaya) berpedoman pada peraturan pemerintah pusat, pengeluaran kerohanian sulit untuk dibuatkan Surat Pertanggungjawaban (SPJ), dan pengeluaran kerohanian yang bersifat tidak universal.

Sistem yang dilaksanakan oleh Undiksha sekarang bukanlah sistem yang pertama kali diterapkan, melainkan sistem yang telah diganti oleh BPK. Implementasi dari sistem penganggaran yang tanpa mencantumkan anggaran kerohanian ini mengalami hambatan saat penerapannya yakni menggantikan dan menyesuaikan sistem lama dengan sistem yang baru tersebut. Untuk mendapatkan dana yang diinginkan tanpa menganggarkannya dalam RAB maka dana yang diperlukan kerohanian akan diselipkan atau disatukan dengan sie atau dana dari divisi lain yang dapat dianggarkan dan mudah untuk dimanipulasi.

\section{SARAN}

Dari hasil penelitian yang telah dilakukan, saran yang dapat diberikan adalah sebaiknya dana untuk kerohanian dapat dicantumkan dalam sistem penganggagaran yang ditetapkan oleh KEMENRISTEKDIKTI dengan sifat yang insidental dan juga hal ini berhubungan dengan transparansi dari laporan yang akan dipertanggungjawabkan nantinya, karena daerah khususnya Bali percaya dengan adanya konsep Tri Hita Karana dimana dalam pengimplementasiannya memerlukan banten yang memerlukan biaya dengan jumlah yang lumayan besar, sehingga dalam menyusun RAB tidak adanya manipulasi data untuk memenuhi kebutuhan tersebut. 
Mini research ini masih jauh dari kata sempurna maka dari itu terdapat saran yang ingin ditunjukan kepada peneliti agar dapat lebih mengembangkan pengetahuan yang dimiliki dalam penulisan karya ilmiah dan lebih terlatih lagi dalam pembuatan mini research, agar data-data yang dimiliki atau digunakan dapat lebih lengkap lagi dan juga dapat bermaanfaat

\section{DAFTARPUSTAKA}

Arta Jaya, I Kadek.2013. "REKONSTRUKSI PERAN GURU PENDIDIKAN AGAMA DALAM MEMBANGUN NILAI KARAKTER SISWA MELALUI IMPLEMENTASI TRI HITA KARANA". Dalam https://ikadekartajaya.wordpress.com/2013/09/10/tri-hita-karana/. Diakses pada 18 Desember 2018.

Bitar. Anggaran : Pengertian, Tipe, Tujuan, Dan Jenis-Jenisnya Beserta Manfaatnya Secara Lengkap. https://gurupendidikan.co.id/anggaran-pengertian-tipe-tujuan-dan-jenisjenisnya-beserta-manfaatnya-secara-lengkap/. Diakses pada 18 Desember 2018.

Indah, Rita. 2 Komponen DI Dalam Penyusunan Anggaran Komprehensif Komponenkomponen. https://www.coursehero.com/file/p1b6ong/2-Komponen-Komponen-DiDalam-Penyusunan-Anggaran-Komprehensif-Komponen-komponen/. Diakses pada 19 Desember 2018.

Niamas, Maila. Fungsi dan Manfaat Anggaran. https://www.akuntansilengkap.com/ekonomi/fungsi-dan-manfaat-anggaran/. Diakses pada 19 Desember 2018.

Mutiara Hindu. 2018. "Pengertian Tri Hita Karana dan Bagian-Bagiannya Serta Contoh Dalam Kehidupan Agama Hindu". Dalam https://www.mutiarahindu.com/search/label/Materi\%20Agama\%20Hindu. Diakses pada 18 Desember 2018.

Peraturan Pemerintahan Republik Indonesia Nomor 26 Tahun 2015 Tentang Bentuk dan Mekanisme Pendanaan Perguruan Tinggi Negeri Badan Hukum. Yasonna H. Laoly disahkan pada 25 Mei 2015.

Peraturan Menteri Keuangan Republik Indonesia Nomor: 65/PMK.02/2015 Tentang Standar Biaya Masukan Tahun Anggaran 2016. Yasonna H. Laoly disahkan pada 26 Maret 2015.

Siahaan. 2004. "TRI HITA KARANA". Dalam https://www.google.co.id/search?q=pengertian+tri+hita+karana+menurut+para+ahli\&r $\mathrm{l}=1 \mathrm{C} 1 \mathrm{GGRV}$ enID759ID759\&oq=penger\&aqs=chrome.0.35i39j69i60j69i57j35i39j0l2 2554j0j2\&sourceid=chrome\&ie=UTF-8. Diakses pada 18 Desember 2018.

Sugiyono. 2013. METODE PENELITIAN KUANTITATIF, KUALITATIF DAN R\&D. Bandung: CV Alfabeta.

Wikipedia Indonesia. 2017. "TRI HITA KARANA". Dalam https://id.wikipedia.org/wiki/Tri Hita Karana. Diakses pada 18 Desember 2018. 